\title{
HISTOLOGICAL SEXUAL DIFFERENCES IN ADULT HUMAN PARATHYROID GLANDS
}

Fating Anita S1, Palikundwar Kiran G²

\section{HOW TO CITE THIS ARTICLE:}

Fating Anita S, Palikundwar Kiran G. "Histological Sexual Differences in Adult Human Parathyroid Glands". Journal of Evolution of Medical and Dental Sciences 2014; Vol. 3, Issue 30, July 28; Page: 8427-8438,

DOI: $10.14260 /$ jemds/2014/3065

ABSTRACT: CONTEXT (BACKGROUND): Increasing problems of calcium deficiency with physiological conditions like pregnancy, lactation etc. it becomes the need of time to focus attention towards these glands as one of the essential entity. Hence we have undertaken this study to have an idea about normal variation in the gland as per sex. AIMS: To reveal sexual differences in adult human parathyroid glands. METHODS AND MATERIAL: Parathyroid glands from 25 autopsied cases of 20 to 59 years were studied after staining with Hematoxylin \& Eosin, Masson's Trichrome \& Reticulin stains. STATISTICAL ANALYSIS: Data is analyzed on statistical software intercooled STATA version 8.0. Data was presented in mean \pm standard deviation \& categorical variables were expressed in percentages. Comparison of oxyphil scores in male \& female was done by unpaired' $t$ ' test. $\mathrm{P}<0.05$ was taken as statistical significance. RESULTS: Stroma composed of short often branching reticular fibres along with blood vessels and fat cells. By statistical examination the amount of fat was more in case of females than in males of same age groups. Oxyphil cells being less numerous than chief cells were distinguished by their dark eosinophilic, granular cytoplasm and were arranged mostly in closely packed groups without interstitial fat in between the cells. Oxyphil cells also found as placed singly among chief cells. It was also observed as continuous masses or anastomosing columns. As compared with males oxyphil cells are more in females. CONCLUSIONS: By statistical analysis 1) Percentage of stromal fat in case of females was slightly greater than in males of same age group. 2) The score of oxyphil cells in females was double to more than triple as compared to male score of same age group. 3) This study is clinically important as hormonal changes occurs early in females than in males and it is in favor of providing supplementary calcium with $\mathrm{D}_{3}$ along with minimal dose of estrogen as age advances in females to avoid fracture of bones due to osteoporosis.

KEYWORDS: Stromal fat Oxyphil cells Sexual differences Quantitative assessment.

INTRODUCTION: Two systems which are of utmost importance in our body are nervous \& endocrine. The parathyroid gland, although small is very essential as hormone secreted by it i.e. parathormone maintain optimal level of calcium in blood.

Our knowledge of the parathyroid glands has greatly increased since they were first discovered in 1850 by Richard Owen ${ }^{1}$ as a small compact yellow glandular body attached to the thyroid gland of an Indian rhinoceros. These glands were unknown to the medical profession until it was rediscovered, named and for the first time adequately described by a Swedish anatomist, Ivar Sandstrom (1880). ${ }^{2}$ Gley was the first one to assign a specific function to glands.

Garven H.S.D.(1957) ${ }^{3}$ described meaning of parathyroid from Greek word 'para' means beside and 'thyreos' means shield \& 'eidos' means like.

Welsh D. A. (1898) ${ }^{4}$ examined the parathyroid glands from 40 human autopsies, published an accurate description of the histology of the normal gland and to which little of fundamental 


\section{ORIGINAL ARTICLE}

importance has been added. He recognized for the first time the "oxyphil" cell, which he distinguished clearly from the predominant "principal" or "chief" cell. Erdheim J. (1903) 5 published his first paper on relationship of parathyroid activity and bone diseases including rickets.

Increasing problems of calcium deficiency with physiological conditions like pregnancy, lactation etc. it becomes the need of time to focus attention towards these glands as one of the essential entity. Hence we have undertaken this study to have an idea about normal variation in the gland as per sex. This work is of immense help in field of medicine like pathology \& surgery etc.

MATERIAL \& METHODS: In the present study parathyroid glands from 25 autopsied cases of age 20 to 59 years, having no hormonal dysfunctions (from death certificates and history from medical records) were collected within 10 to 12 hours after death, from autopsy room of Department of Forensic medicine \& Toxicology, Government Medical College, Nagpur. To reveal sexual differences, specimens of glands of both male and female have been divided into 4 age groups i.e. 20 to 29,30 to 39,40 to $49 \& 50$ to 59 .

The specimens were fixed in formalin for 24 hours. After proper preservation \& fixation, parathyroid tissues were processed for paraffin sections. Then serial transverse sections of 5 to 7 microns thickness were taken on Spencer rotary microtome. Sections were stained with Haematoxylin \& Eosin (H \& E), Masson's Trichrome and Reticulin stains. All the sections were studied under binocular compound light research microscope \& microphotography was done with Karlzeiss photomicrographic unit low power to oil immersion.

Calculation of \% of stromal fat: Stromal fat was determined with the aid of net micrometer of 20x20 squares (400 points) (Fig no 10) in a $10 \mathrm{x}$ focusable wide field eye piece of binocular microscope using a $4 \mathrm{x}$ objective, similar to the point counting method by Weibel E.R.(1973)6. The percentage of stromal fat was calculated as per number of points on fat divided by number of points on parenchyma or interstitial tissue.

$\mathrm{P}=\mathrm{h} / \mathrm{h}+\mathrm{m}$.

$\mathrm{p}=$ Percentage of stromal fat.

$\mathrm{h}=$ Number of points on stromal fat.

$\mathrm{m}=$ Number of points over other components.

Calculation of average oxyphil scores: A quantitative assessment was made of the number of oxyphil cells by measuring the diameter in microns of each group of oxyphil cells in sections taken through the maximum diameter of each gland and summating the areas thus obtained by the formula $\prod$ ab, where 'a' \& 'b' represent one half of each major \& minor axis respectively, as stated by Christie A. C. $(1967){ }^{7}$

Statistical Analysis: Data is analyzed on statistical software intercooled STATA version 8.0. Data was presented in mean \pm standard deviation and categorical variables are expressed in percentages. Comparison of oxyphil scores in male and female was done by unpaired't' test. $\mathrm{P}<0.05$ was taken as statistical significance. 


\section{ORIGINAL ARTICLE}

Statistical formulae for calculations:

Where $\rightarrow \mathrm{x}=$ mean

1) Mean $\rightarrow x=\sum \bar{x} / n$

$\mathrm{x}=$ individual value

$\mathrm{n}=$ number of observations

$\sum \mathrm{x}=$ sum of all measurements

2) Standard deviation $\rightarrow$ S. D. $=\sqrt{\sum \overline{(\overline{X-X})^{2} / n}}$

OBSERVATIONS: Entire specimens of parathyroid used in the present study were normal. Quantitative assessment of tissue was also done. Observations were done under following headings:

1) Stromal fat

2) Oxyphil cells

Stromal fat: Stroma composed of short often branching reticular fibres (fig 1) along with blood vessels (fig 2)and fat cells in it (fig 3) was observed. Large fat cells were observed in females of age groups 40 to 49 years (fig 4). Quantitative assessment of stromal fat in different age groups of both sexes was done and by statistical examination it was found that the amount of fat was more in case of females than in males of same age groups as shown in Table no 1.

Oxyphil cells: Oxyphil cells were observed and quantitatively studied. Oxyphil cells, being less numerous than chief cells, were distinguished by their dark eosinophilic, granular cytoplasm. (Fig no 5 \& 9). They were arranged mostly in closely packed groups without interstitial fat in between the cells (fig no 6). A large encapsulated mass of oxyphil cells seen at periphery of gland near its capsule (fig no 7). Oxyphil cells were also seen as placed singly among chief cells (fig no 8) or as continuous masses or anastomosing columns (fig no 3). Average oxyphil scores were calculated and shown in table no. 2 .

DISCUSSION: The present study was carried out to reveal sexual differences about stromal fat \& oxyphil cells in adult human parathyroid glands. Present study revealed stroma composed of reticular fibres, blood vessels \& fat cells. Quantitative assessment showed that percentage of stromal fat was slightly more in females than in case of males.

Gilmour J. R. \& Martin W. J. (1937), ${ }^{8}$ studied parathyroid tissues from 527 autopsied cases \& by statistical examination observed that in adults the mean percentage volume of fat in interstitial tissue i. e. the stromal fat is slightly greater in females than in males in adults. Gilmour J. R. (1939) ${ }^{9}$ observed adipose cells, varying in number in interstitial tissue. Increase adipose cells were seen in females than in males. The present finding is correlated with these findings.

Present study revealed that oxyphil cells were less numerous than chief cells, placed either at periphery of gland adjacent to capsule or in the centre of gland. The oxyphil cells showing dark eosinophilic granules. By statistical examinations, oxyphil cells were more in number in females than in males of same age groups.

Sandstrom I. (1879-80)2, Koopman H. (1921) ${ }^{10}$ stated that the granular cells in groups undoubtedly oxyphils has tendency to lie near the surface of gland. Leeson T. L., Leeson C. R. \& Paparo 


\section{ORIGINAL ARTICLE}

A. A. (1988) ${ }^{11}$, Pal G. P. (2005) ${ }^{12}$ quoted oxyphil cells as less numerous than the chief cells. The present finding revealed the same. Christie A.C. (1967) ${ }^{7}$ studied parathyroid tissues of 600 cases and observed that oxyphil score in females varies from double to more than triple compared to the male scores for each decade. Gilmour J. R. (1939), ${ }^{9}$ Arey L. B. (1974), ${ }^{13}$ Young B. and Heath J.W. (2000) ${ }^{14}$ stated arrangement of oxyphil cells in groups or as continuous masses or singly in between the chief cells. Gilmour J. R. (1939) ${ }^{9}$ observed tendency of oxyphil cells to lie near the surface of gland with rare interstitial fat cells in between. Current findings showed the same.

Maximow A. A., Bloom W. (1949) ${ }^{15}$ quoted that oxyphil cells are arranged as continuous masses \& anastomosing columns whereas Gardner D. L., Dodds T. C. (1976) ${ }^{16}$ stated their arrangement in cords. These findings correlated with present study.

Maximow A. A., Bloom W. (1949) ${ }^{15}$ stated that great majority of adenomatous nodules of oxyphil cells are highly vascular with widely patent capillaries filled with blood. This histological feature has always been regarded as a sign of active functional activity in the case of endocrine glands.

Gilmour J. R. (1939)9 ${ }^{9}$ studied parathyroid tissues in great details from 428 autopsied cases and observed oxyphil cells having acidophilic granular cytoplasm. Current findings revealed the same. Trier J. S. (1958) ${ }^{17}$ by EM study in macque monkey, suspected that granules in the oxyphil cells are mitochondria. EM study by Gaillard et al (1965),18 Munger B. L. \& Roth S. I. (1963),19 Roth S. I., Capen C. C. (1974) ${ }^{20}$ and Capen C. C. (1975) ${ }^{21}$ Suggested that oxyphil cells are not involved in hormone synthesis or secretion though abundant mitochondria suggest a high metabolic activity.

Morgan J.R.E. (1936) and Garven H.S.D. (1957) ${ }^{22}$ stated that mitotic figures are seen in the oxyphil cells. Bevelander G. (1965) ${ }^{23}$ stated that the presence of oxyphil cells is an indication of activity on the part of the gland but experimental evidence does not support this view it seems probable that they are degenerating cells.

Wheater P.R., Burkitt H. G. \& Daniel V. G. (1979) ${ }^{24}$ stated that these cells do not secrete hormones except in certain pathological conditions. According to Cormak D. H. (1984)25, Kelly D. E., Wood R. L., Enders A. C(1984) ${ }^{26}$ that oxyphil cells may represent a non-secretary stage in life cycle of chief cells. Castleman B. and Mallory T. B. (1935) ${ }^{27}$ studied parathyroid tissues extensively in 150 autopsied cases and concluded from their study of tumors that the dark oxyphil cells may be senile.

Roth S. I. (1996) ${ }^{28}$ reported that the oxyphil cells are the result of proliferation of mitochondria in the chief cells. This can occur in individual chief cells, resulting in individual oxyphil cells among the chief cells. He further concluded that oxyphil cells in normal gland do not secrete PTH in absence of chromogranin and PTH in them.

Tremblay G. \& Pearse A. G. E. (1959) ${ }^{29}$ first studied oxidative enzymes in monkey's parathyroid glands and their studies of various enzyme systems within the cells do not indicate degenerative changes. Balogh K. Jr and Cohen R. B. (1961) ${ }^{30}$, Tremblay G., Cartier G.E. \& Fischer R. (1961) ${ }^{31}$ demonstrated a high level of activity of a wide variety of oxidative enzymes in the oxyphil cells. Munger B. L. and Roth S. I. (1963) ${ }^{19}$ showed the lack of organelles necessary for protein synthesis and secretion in normal oxyphil cells.

Christie A. C. (1955) 32 stated that oxyphil cells may be degenerate forms of chief cells. However there is no histological evidence for this assumption. In fact, the reverse is more likely for the following reasons: 


\section{ORIGINAL ARTICLE}

1) The nodules are highly vascular.

2) Only occasionally do the cells show evidence of degeneration

3) They show strong histochemical reaction for phospholipids similar to the pituitary acidophil cells.

In females during 30 to 40 years of age (gestational age) need of calcium increases and in post-menopausal age amount of estrogen decreases leads to disturbance in calcium metabolism resulting into osteoporosis which is corrected by supplementary oral calcium with D3, suggesting reduction in parathormone.

More number of oxyphil cells having mitochondria in the form of eosinophilic granules and more amount of stromal fat probably leads to reduction in parathormone level in females.

Chief cells transformed into oxyphil cells resulting into less amount of parathormone leads to osteoporosis.

This study can be of great help in the field of medicine.

CONCLUSIONS: By statistical analysis 1) Percentage of stromal fat in case of females was slightly greater than in males of same age group. 2) The score of oxyphil cells in females is double to more than triple as compared to male score of same age group. 3)This study is clinically important as hormonal changes occurs early in females than in males and it is in favor of providing supplementary calcium with $\mathrm{D}_{3}$ along with minimal dose of estrogen as age advances in females to avoid fracture of bones due to osteoporosis.

\section{REFERENCES:}

1. Owen R. quoted by Ashley D J B. (1990) Evan's Histological appearances of tumours, 4 th edi, Churchill Livingstone (1851-52).

2. Sandstrom I. Om enny Kortel hos menniskan och atskilliga daggdjur.Upsala Ldkaref. F§rh., I5, 44I-470. (Cited by Welsh.) (1880).

3. Garven H.S.D. A Student's histology, E \&S Livingstone Ltd. (1957).

4. Welsh D A. Concerning the parathyroid glands: a critical, anatomical \& experimental study. J Anat \& Physiol, 32, 380-402. (1897-98).

5. Erdheim J, Erdheim J. Zur normalen und pathologischen Histologie der Glandul thyreoidea, parathyreoidea und Hypophysis. Beitr. Z. path. Anat. u. z.all Pathol., I903, 33, I58-236. (1903).

6. Weibel E R. quoted by Dekker A, Dunsford H A, Geyer S J. (1979) The normal parathyroid gland at autopsy: The significance of stromal fat in adult patients. J Pathol 128: 127-132.(1973) .

7. Christie A C. The parathyroid oxyphil cells. J Clin Pathol 20:591-602 (1967).

8. Gilmour J R, Martin W J. The weight of the parathyroid glands. J Pathol Bacteriol 44:431-462 (1937).

9. Gilmour J R. The normal histology of the parathyroid glands. J Pathol Bacteriol 48: 187-222. (1939).

10. Koopman H. quoted by Gilmour J R. (1939) The normal histology of the parathyroid glands. J Pathol Bacteriol 48: 187-222. (1921).

11. Leeson T L, Leeson C R, Paparo A A. Text/ Atlas of Histology, 3rd edition, W. B. Saunders Company. (1988).

12. Pal G P. Textbook of Histology. Paras Medical Publisher, (2005). 


\section{ORIGINAL ARTICLE}

13. Arey L.B. Human histology 4th edi, W.B. Saunders Company. (1974).

14. Young B, Heath J W. (2000) Wheater's functional histology, 4th edi, Churchill Livingstone. (2000).

15. Maximow A A, Bloom W. A textbook of Histology, 5th edi, W.B. Saunders Company. (1949).

16. Gardner D L, Dodds T C. Human Histology 3rd edi, Churchill Livingstone. (1976).

17. Trier J S. (1958) quoted by Christie A C. The parathyroid oxyphil cells. J Clin Pathol 20:591-602. (1967).

18. Gaillard P J, Talmage R V, Buddy A M. quoted by Gray H. (2005) Gray's Anatomy, 39th edi, Churchill Livingstone. (1965).

19. Munger B L, Roth S I. quoted by Damjanov I. and Linder J., Anderson's Pathology, Vol 2, 10 th edi, Mosby Company. (1963).

20. Roth S I, Capen C C. quoted by Gray H. (2005) Gray's Anatomy, 39th edi, Churchill Livingstone. (1974).

21. Capen C C. quoted by Gray H. (2005) Gray's Anatomy, 39th edi, Churchill Livingstone. (1974).

22. Morgan J R E. quoted by Gilmour J R. (1939) The normal histology of the parathyroid glands. J Pathol Bacteriol 48: 187-222. (1936).

23. Bevelander G. (1965) Essentials of Histology, 5th edi, The C. V. Mosby Company, Toppan Company Ltd. (1965).

24. Wheater P R, Burkitt H G, Daniel V G. Functional Histology, 1st edi, Churchill Livingstone.(1979).

25. Cormack D H. Introduction to Histology, 1st edi, J. B Lippincott Company. (1984).

26. Kelly D E, Wood R L, Enders A C. Bailey's textbook of microscopic anatomy, 18th edition, Williams and Wilkins. (1984).

27. Castleman B, Mallory T B. The pathology of parathyroid gland in hyperparathyroidism. Am J of Pathol: 1-72. (1935).

28. Roth S. I. quoted by Damjanov I. and Linder J. (1996) Anderson's Pathology, Vol 2, 10th edi, Mosby Company. (1996).

29. Tremblay G, Pearse A G E. quoted by Christie A C. (1967) The parathyroid oxyphil cells. J Clin Pathol 20:591-602. (1959).

30. Balough K. Jr, Cohen R B. quoted by Damjanov I. and Linder J. (1996) Anderson's Pathology, Vol 2, 10th edi, Mosby Company. (1961).

31. Tremblay G, Cartier G E. Histochemical study of oxidative enzymes in the human parathyroid. Endocrinology 69:658-661. (1961).

32. Christie A C. Quoted by Christie A C. (1967) The parathyroid oxyphil cells. J Clin Pathol 20:591602. (1955). 


\section{ORIGINAL ARTICLE}

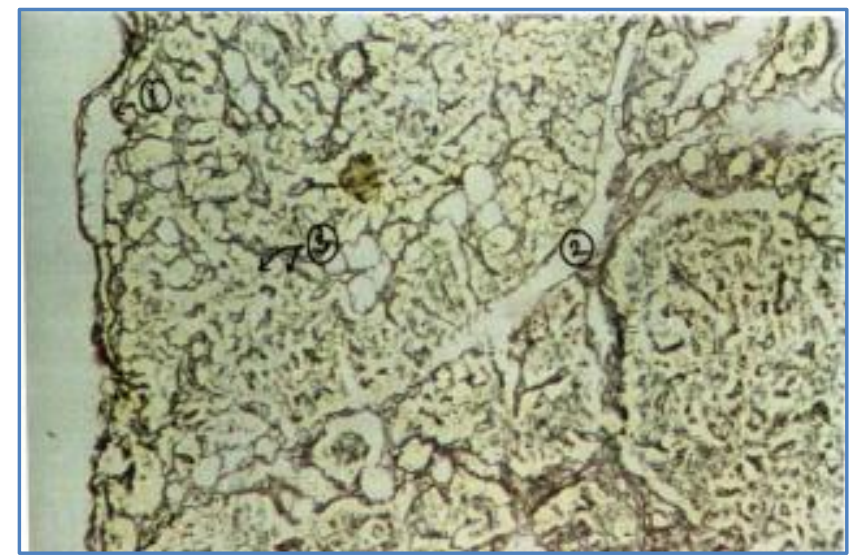

Fig. 1: 25 yrs. /F, Reticulin stain, x100

1) Collagen fibres 2 ) Septa 3 ) Reticular fibres

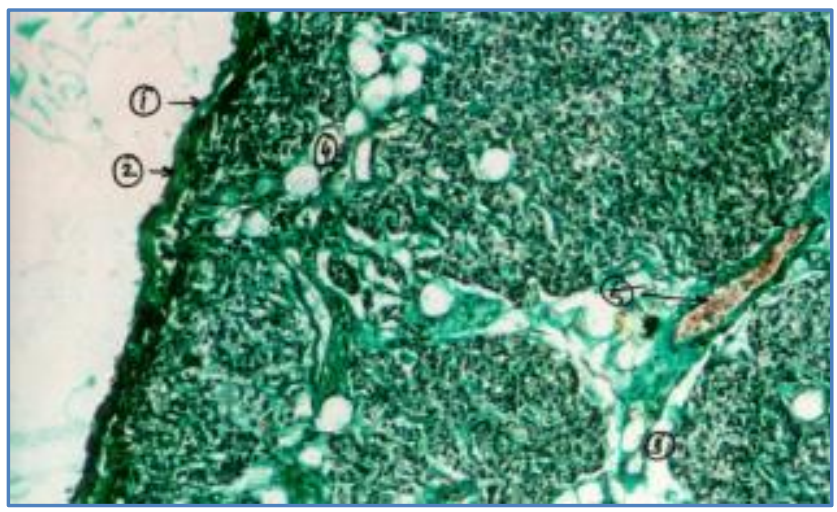

Fig. 2: 23yrs /M, Masson's Trichrome stain,x100

1) Capsule 2) Collagen fibres 3) Septa 4) Fat cells 5) Blood vessel

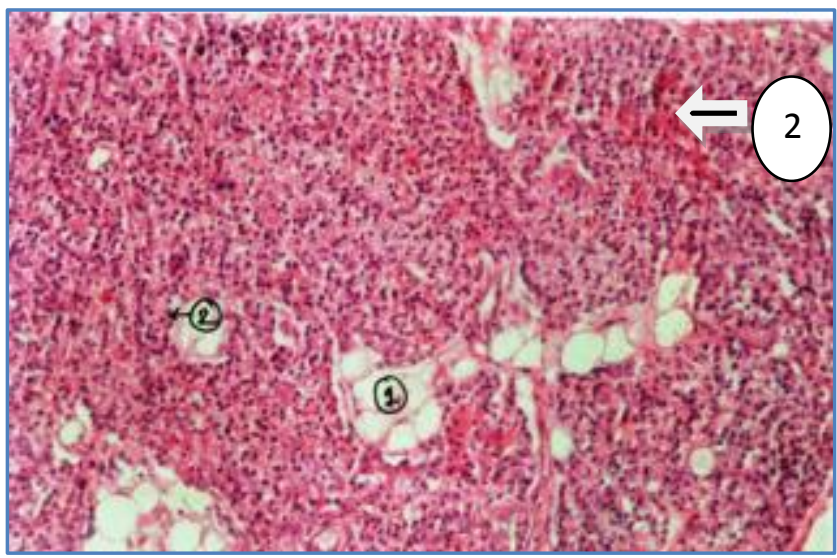

Fig. 3: 35yrs /M, H \& E stain,x100

1) Fat cells 2) Oxyphil cells in anastomosing cords 


\section{ORIGINAL ARTICLE}

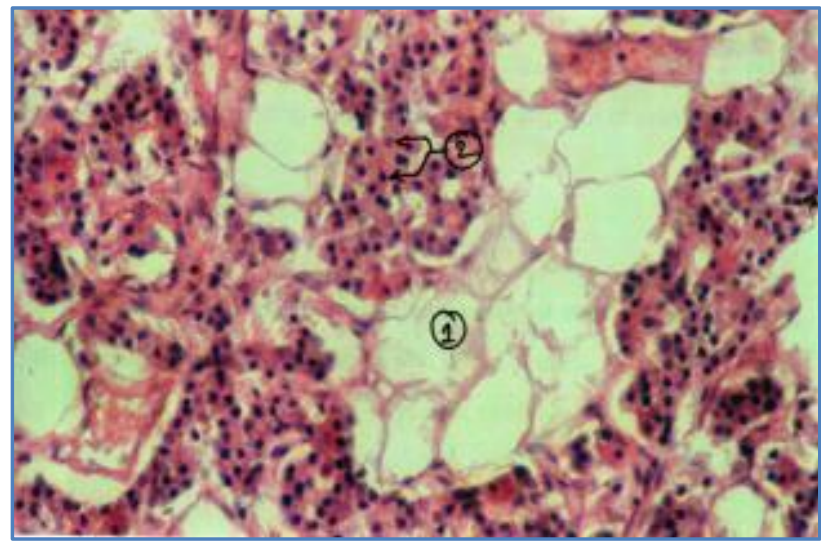

Fig. 4: 44 yrs / F, H \& E stain, x200

1) Fat cells 2) Chief cells

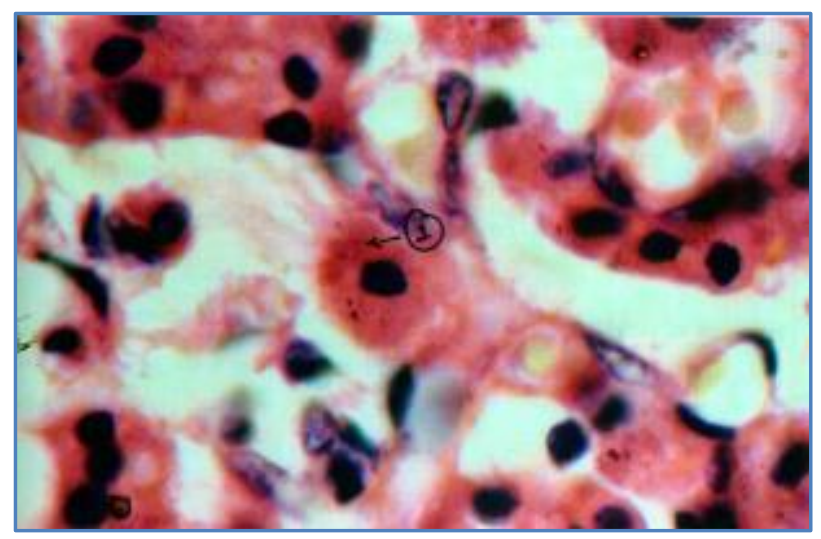

Fig. 5: 33yrs/ M, H \& E stain, x1000

1) Granules of oxyphil cells

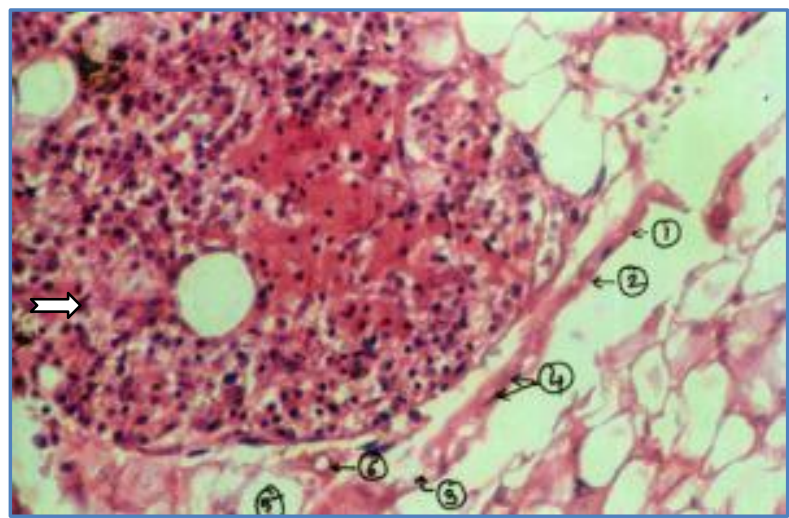

Fig. 6: 52 yrs/ F, H \& E stain, x200, showing oxyphil cells in group

1) Capsule 2) Collagen fibres 3 ) Elastic fibres 4) Nuclei of connective tissue cells 5) Fat cells 6) Blood vessels 


\section{ORIGINAL ARTICLE}

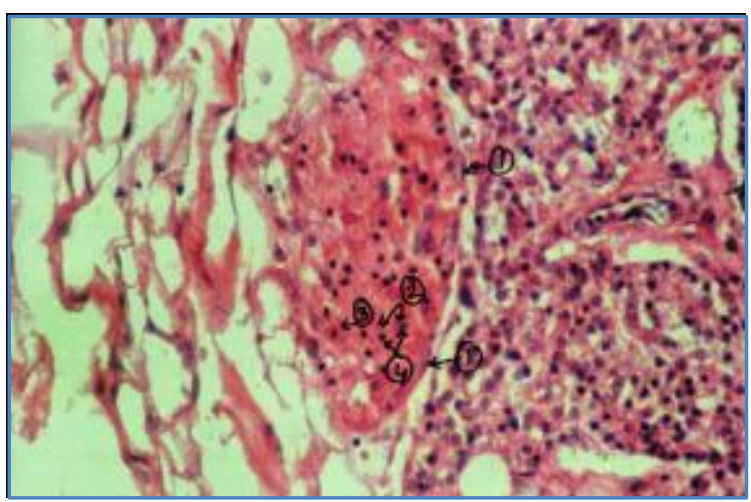

Fig. 7: 59 yrs/F, H \& E stain, x 200

1) Nuclei of connective tissue cells

2), 3) \& 4) Oxyphil cells in groups at the periphery

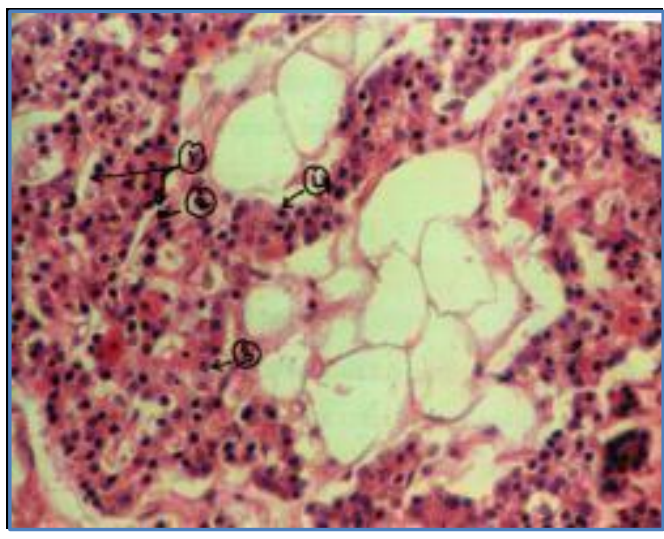

Fig. 8: 56 yrs/ F, H \& E stain, x200

1) Sinusoidal blood vessels 2) Basal lamina 3) \& 4) Chief cells

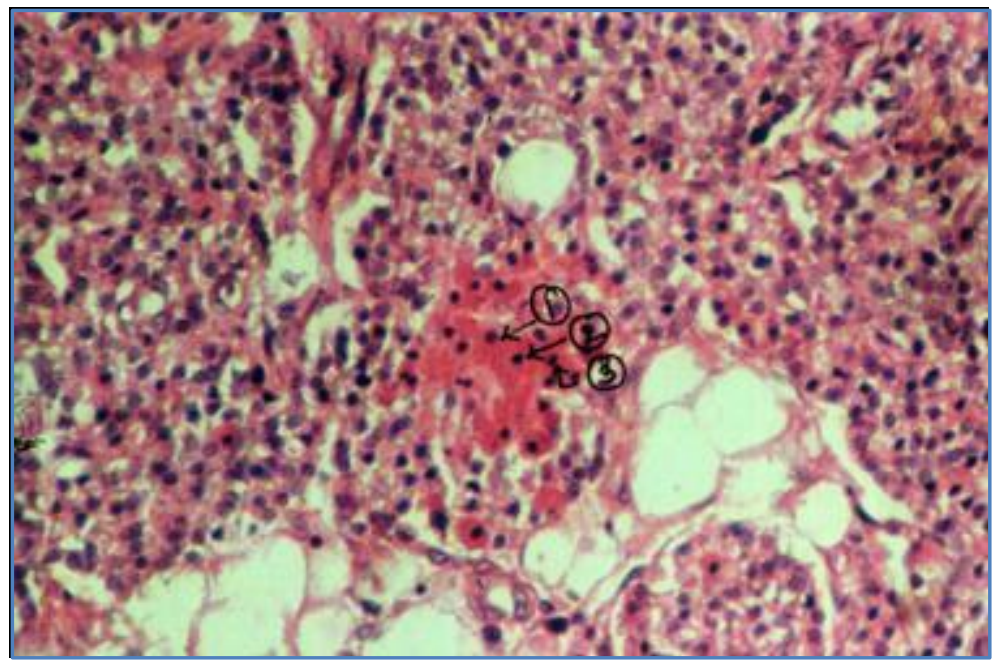

Fig no 9: 52 yrs/F, H \& E stain, x200

1) Oxyphil cells 2) Granular eosinophilic cytoplasm 3) Hyperchromatic nuclei 


\section{ORIGINAL ARTICLE}

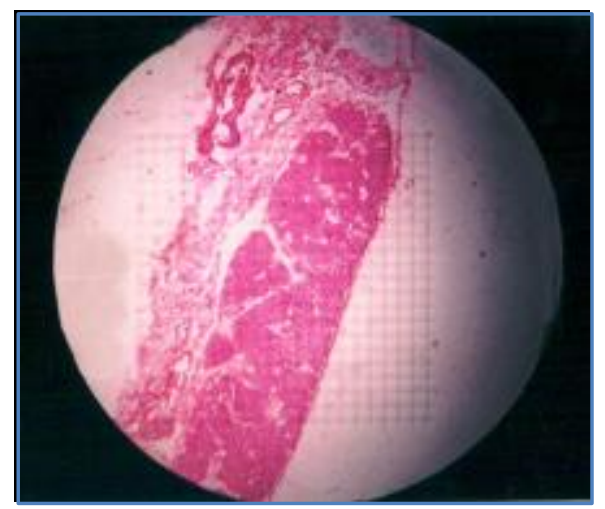

\section{Fig. 10: Net micrometer of 20 × 20 squares ( 400 points)}

\begin{tabular}{|c|c|c|}
\hline Age groups (years) & Male & Female \\
\hline $20-29$ & 3.66 & 4.0 \\
\hline $30-39$ & 8.2 & 8.5 \\
\hline $40-49$ & 38.13 & 38.56 \\
\hline $50-59$ & 14.9 & 18.3 \\
\hline Overall mean \pm S.D. & $17.06 \pm 14.28$ & $19.57 \pm 15.74$ \\
\hline
\end{tabular}

Table 1: Showing average percentage of stromal fat in each decade of both sexes

For male $\&$ female difference $\rightarrow p=0.6839$, Non- Significant

In the present study average percentage of stromal fat in males was 3.66 and in females it was 4.0 in age group between 29-29 years. Average percentage of stromal fat in males was 8.2 and in females it was 8.5 in age group between 30-39 years. Average percentage of stromal fat in males was 38.13 and in females it was 38.56 in age group between $40-49$ years. Average percentage of stromal fat in males was 14.9 and in females it was 18.3 in age group between $50-59$ years.

The overall mean in males was $17.06 \pm 14.28 \&$ in females was $19.57 \pm 15.74$

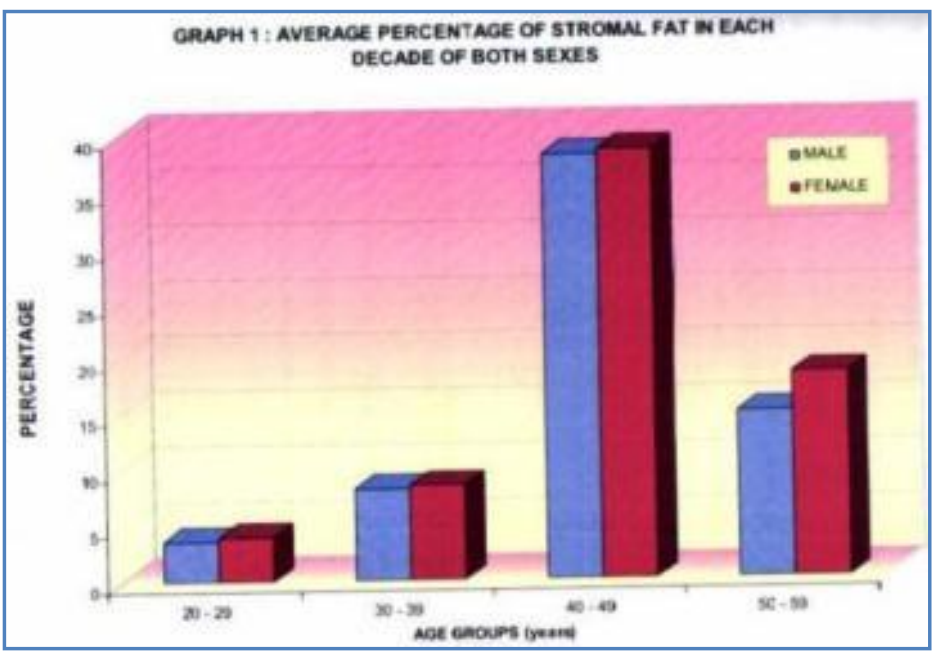




\section{ORIGINAL ARTICLE}

\begin{tabular}{|c|c|c|}
\hline Age groups (years) & Male & Female \\
\hline $20-29$ & 6.0 & 15.0 \\
\hline $30-39$ & 18.0 & 85.50 \\
\hline $40-49$ & 35.25 & 199.33 \\
\hline $50-59$ & 150.0 & 308.33 \\
\hline Overall meanะS.D. & $55.40 \pm 16.02$ & $172.40 \pm 118.13$ \\
\hline
\end{tabular}

For male $\&$ female difference $\rightarrow p=0.0036$, highly significant

In the present study average oxyphil scores in males was $6 \times 10^{3}$ square microns/gland and in females it was $15 \times 10^{3}$ square microns/gland in age group between 29-29 years. Average oxyphil scores in males was $18 \times 10^{3}$ square microns/gland and in females it was $85.50 \times 10^{3}$ square microns/gland in age group between $30-39$ years.

Average oxyphil scores in males was $35.25 \times 10^{3}$ square microns/gland and in females it was $199.33 \times 10^{3}$ square microns/gland in age group between 40-49 years. Average percentage oxyphil scores in males was $150 \times 10^{3}$ square microns/gland and in females it was $308.33 \times 10^{3}$ square microns/gland in age group between 50-59 years. The overall mean of average oxyphil scores in males was $55.4 \pm 16.02 \times 10^{3}$ square microns/gland) and in females it was $172.4 \pm 118.13 \times 10^{3}$ square microns/gland.

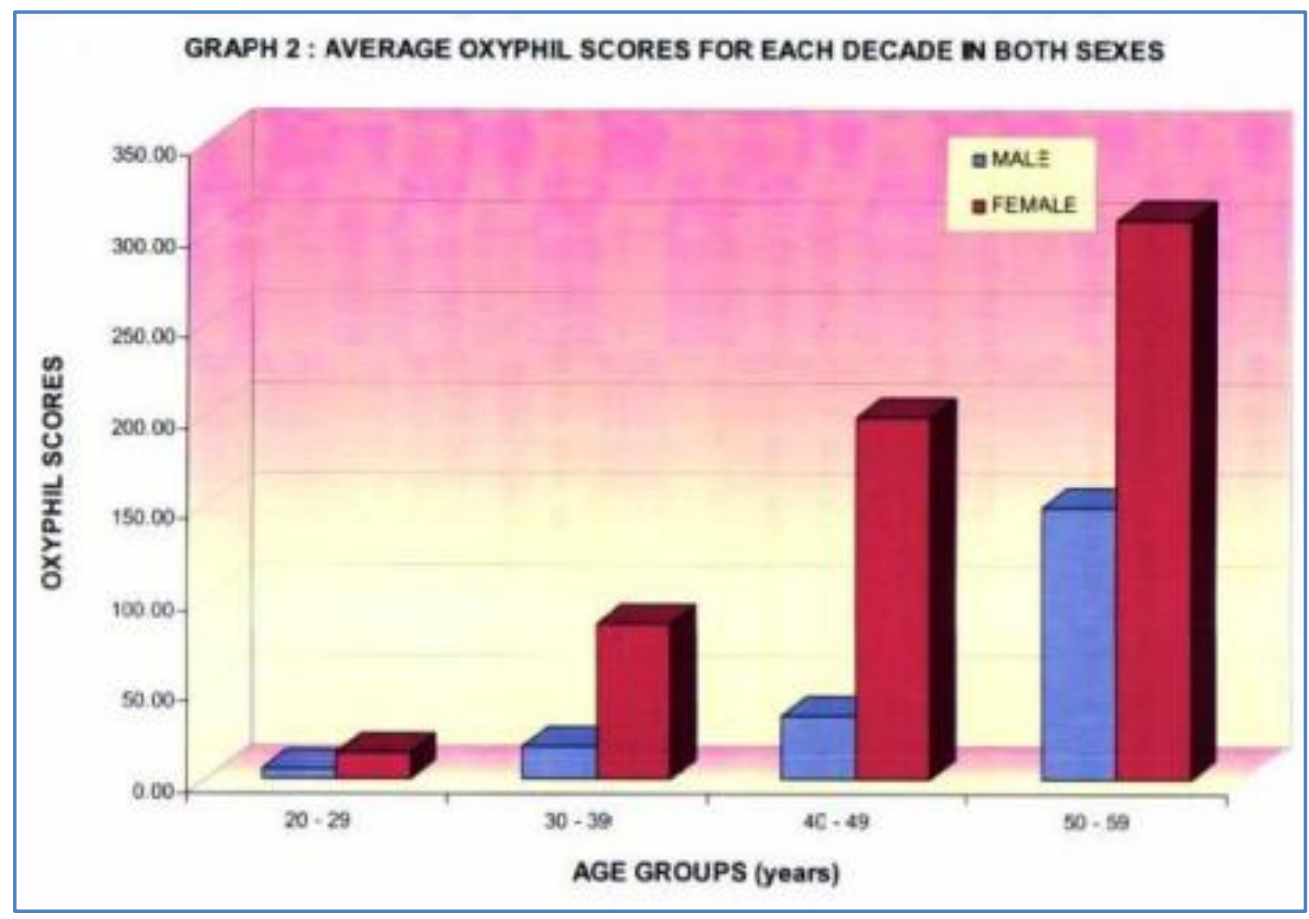




\section{ORIGINAL ARTICLE}

\section{AUTHORS:}

1. Fating Anita $S$.

2. Palikundwar Kiran G.

\section{PARTICULARS OF CONTRIBUTORS:}

1. Associate Professor, Department of Anatomy, Dr. Ulhas Patil Medical College, Jalgaon Kh, M. H.

2. Professor and HOD, Department of Anatomy, Revera Institute of Medical Sciences, Vikramgarh, Thane, M. H.
NAME ADDRESS EMAIL ID OF THE

\section{CORRESPONDING AUTHOR:}

Dr. Anita Shriram Fating,

Department of Anatomy,

Associate Professor,

Dr. Ulhas Patil Medical College \& Hospital,

Jalgaon (Khurd)-425309, M. H, India.

Email: aanujdeshmukh@rediffmail.com

Date of Submission: 09/07/2014. Date of Peer Review: 10/07/2014.

Date of Acceptance: 18/07/2014.

Date of Publishing: 24/07/2014. 